\title{
Factors Contributing To Independent Venture Capital Successful Exits
}

\author{
David A. Blum, Northcentral University, USA
}

\begin{abstract}
Independent venture capital (IVC) firms invest in nascent, high growth, high risk, and market scalable companies for the purposes of achieving a successful exit. An exit is the primary method IVCs use to receive a return on investment. Although IVCs provide capital funding, strategic advice, and access to an extensive network of potential suppliers and customers, approximately $20 \%$ of portfolio firms reach a successful exit.
\end{abstract}

This paper outlines the job of the IVC, the due diligence and staging processes, and addresses four factors that might account for the low successful exit rate: 1) diseconomy of scale in the venture capital industry, 2) emphasis on quick exits rather than building long-term sustainable companies, 3) exits that are independent of fund inflows, and 4) financial and market forecasts that appear to trump market conditions. This paper addresses a gap in literature by providing four factors contributing to low IVC success exit rates. To achieve higher exit successes, IVCs need to cease providing funding capital, especially during times of high capital inflows, and stop chasing portfolio firms that have little chance of achieving a successful exit.

Keywords: Independent Venture Capital; Due Diligence; Staging; Successful Exits; Portfolio Firms

\section{INTRODUCTION}

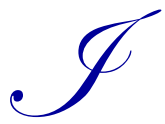

ndependent venture capitalists (IVCs) invest in new, high growth, high risk, and market scalable companies known as portfolio firms. IVCs stimulate innovation, job creation, technology improvements, enhancement of international competitiveness, and economic growth (Li \& Zahra, 2012). In addition, IVC firms fill a critical intermediary function by not only providing equity funding to portfolio firms, but creating value for high net worth investors (Jackson, Bates, \& Bradford, 2012; Olsson, Frydenberg, Jakobsen, \& Jessen, 2010; Schertler \& Tykvova, 2011). Zhang, Aksu, and Wang (2012) found that IVC firms play a critical role in positively shaping new firms.

The proportion of companies receiving IVC funding is very low and is not a primary source of capital for most businesses in the United States (Rajan, 2010). IVC firms receive thousands of requests for funding per year (Cumming, Schmidt, \& Walz, 2010). Portfolio firms receiving IVC funding account for one-sixth of $1 \%$ of all new businesses per year, that obtain capital funding (Kaplan \& Lerner, 2010). Although IVCs screen, conduct due diligence, provide funds in stages, offer strategic advice, and make available valuable network contacts, approximately $20 \%$ of portfolio companies who were among the one-sixth of $1 \%$ receiving IVC funding survive to a successful exit (Kaplan \& Lerner, 2010 \& Strömsten \& Waluszewski, 2012).

A successful exit occurs when the IVC realizes a return on investment (ROI) by selling an interest in the portfolio company by an initial public offering (IPO), by having the portfolio firm acquired by another company, sold to another company, or merged with another organization (Strömsten \& Waluszewski, 2012). IVCs' portfolio successful exits are calculated as the ratio of successful venture investments over the total number of portfolio firms invested (Bartkus et al., 2013). At the time when the IVC considers liquidating interest in the portfolio firm, the portfolio firm is usually in its youthful stage of the business lifecycle. A portfolio company is typically "sold" after experiencing a degree of financial and market success (Bamford \& Douthett, 2013). 
The focus of this paper is to explore the factors contributing to why after extensive screening, stringent due diligence processes, staged funding, and providing strategic advice and access to established business networks, IVC successful exits are at approximately $20 \%$. The literature review outlines the job of the IVC, the due diligence and staging processes, and four factors contributing to low IVC success rates. The discussion begins with the job of the IVC.

\section{LITERATURE REVIEW}

\section{The Job Of The Independent Venture Capitalist}

Most IVCs come to venture capital from technology-based industries as executives and as start-up entrepreneurs. IVCs also come from prestigious business programs at selected universities in California, Massachusetts, and Pennsylvania with a specialization in financial management. As part of the job, IVCs do not just provide funding; they provide managerial services, monitoring of the portfolio company, offer strategic advice, and access to an extensive network of potential customers and suppliers (Bhagat, 2013). IVCs fund ventures at different stages as long as uncertainties do not make further funding risk assessments prohibitive. Receiving thousands of business plans yearly, IVCs scrutinize most business plans, meet with entrepreneurial teams, valuate the new business, discern market scalability, and determine whether the product or service meets an everyday need (Blum, 2013).

The job of a venture capitalist is broad based. IVCs seek to generate a stream of positive cash flow and to create value while skillfully evaluating funding opportunities. After all relevant evaluations and due diligence process have been completed, the IVC must decide whether to invest in the portfolio company. Once the portfolio company meets IVCs funding requirements, the IVC negotiates the terms of the investment relationship based on portfolio valuation methods, usually in terms of multiples or comparables. The IVC monitors the portfolio firm by serving on the board of directors. To achieve a successful exit, IVCs seek to liquidate investments based on valuations and rate of return. IVCs collaborate with investment banks and market movers to facilitate an IPO, merger, acquisition, or sell.

Raising funds is a time-consuming and difficult endeavor for the IVC. They raise funds from pension funds, insurance companies, foundations, institutional investors, and high net worth persons (NVCA, 2014). Individuals who invest in venture capital funds are limited partners (NVCA, 2014). IVCs who manage funds are general partners and have a fiduciary responsibility to the limited partners (NVCA, 2014).

Factoring for the growth of the economy and the stock market, Rajan (2010) and Jackson et al. (2012) inferred the availability of IVC funding sources has increased steadily over past years, although IVC investing in early stage companies has a lower likelihood of reaching an exit (Bartkus, Hassan, \& Ngene, 2013).

\section{Due Diligence}

After the initial screening but before the IVC decides to invest in the portfolio firm, the IVC performs due diligence. During this process, IVCs focus on reducing investment risk. Before making a financial investment, IVCs perform extensive research on the portfolio firm's products, management team, and internal and external competitive environments. Due diligence is measured by the total hours an IVC spends performing research on a preportfolio company (Blum, 2014). IVCs perform due diligence to reduce uncertainty in early stage investments.

As part of the due diligence process, IVCs review:

- $\quad$ Pending legal action

- $\quad$ Provisional and approved patents

- $\quad$ Market trends, potential, and strategy

- Whether the product or service meets an everyday need

- $\quad$ The competitive environment

- Whether the company has a scalable technology

- $\quad$ The portfolio firm's competitive advantage (Wiltbank, Read, Dew, \& Sarasvathy, 2009)

Copyright by author(s); CC-BY 
The effort spent by IVCs performing due diligence is generally proportionate to the anticipated investment funding size (Wiltbank et al., 2009). From screening to seed or early funding, the due diligence process takes approximately three to six months (Lehtonen \& Lahti, 2009; Yung, 2009). IVCs who conduct extensive due diligence and are more involved in the post investment operations of the portfolio firm experience significantly higher ROI through a successful exit (Wiltbank et al., 2009).

The most significant aspect of due diligence is the use of comparables from online venture capital databases to determine valuation price and evaluate similar portfolio firms before deciding to invest. Based on comparables, IVCs use multiples ranging from $3 \mathrm{x}$ to $10 \mathrm{x}$ based on revenue and sometimes earnings before interest, taxes, and amortization within three to five years of funding (Blum, 2014). For example, if an IVC invests $\$ 10$ million dollars in a start-up, the IVC expects a minimum return of $\$ 30$ million in three to five years. IVCs also consult with market experts to understand market trends and requirements (Blum, 2014).

Qualitative factors enter into the due diligence process. IVCs consider "gut feelings" related to investing in the portfolio firm, usually based on the relationship with management (Blum, 2014). IVCs seek good personal chemistry with the portfolio management team. IVCs should have confidence in the portfolio firm's management's ability to understand industry standards and demands. IVCs use qualitative and quantitative factors to determine how much time (three to five years) and money (\$10 million, $\$ 50$ million, $\$ 100$ million) are needed to achieve a successful exit and required return on investment (Blum, 2014).

\section{Staging Process}

After a successful due diligence process, the IVC will consider funding the portfolio company in stages. Most IVCs invest in software services, social and Internet media, cleantech, wireless communications, medical, health, and life science technologies companies located primarily in California and Massachusetts (NVCA, 2014). Differences exist during the staging process and across industry sectors (Ecer \& Khalid, 2013).

The funding stages are:

Seed Stage: The portfolio company has a concept, prototype, or product under development but is normally not operational. The company has been in business less than 18 months (Ecer \& Khalid, 2013). A business plan might exist and or the company might be a concept on a napkin (Ecer \& Khalid, 2013).

Early Stage: The portfolio company has a product or service in testing, in pilot production, or it might be commercially available (Ecer \& Khalid, 2013). The company could be generating revenues and is usually in business for less than three years (Ecer \& Khalid, 2013).

Expansion Stage: Product(s) or service(s) are in production (Ecer \& Khalid, 2013). The company exhibits revenue growth and might be starting to be profitable (Ecer \& Khalid, 2013). The company is usually in business more than three years (Ecer \& Khalid, 2013).

Late Stage: The company's product(s) or service(s) are commercially available (Ecer \& Khalid, 2013), and the company is generating sustained revenues and usually has a positive cash flow (Ecer \& Khalid, 2013). The company is likely profitable. In the late stage, the company might include separate and distinct operating divisions (Ecer \& Khalid, 2013) and in the late stage, they might be ready to be acquired, sold, merged, and exited by the IVC via an IPO.

Staging is a common practice and an important activity to mitigate IVC risk by limiting financial exposure in subsequent rounds, reducing the effects of asymmetry of information and abandoning further funding if low return on investment is forecasted (Dahiya \& Ray, 2012; Geronikolaou \& Papachristou, 2011; Hsu, 2010; Smolarski $\&$ Kut, 2011). Reducing economic uncertainties is a factor in staged financing influencing IVC decision-making (Li $\&$ Mahoney, 2011). The IVC firm faces the maximum risk in the staging process during the seed round (Smolarski \& Kut, 2011). By staging, the IVC firm invests capital and provides additional value-added services, such as strategic advice and access to established IVC networks, to the portfolio firm (Smolarski \& Kut, 2011). Staged 
financing helps the IVC to define goals, monitor the progress of the portfolio firm, and provides the IVC with the option to abandon, delay, or invest funds in the portfolio company (Driouchi, Leseure, \& Bennett, 2009; Rajan, 2010; Smolarski \& Kut, 2011).

\section{Four Factors Contributing To 20\% Success Rate}

After conducting an in-depth due diligence process and staged funding, approximately $80 \%$ of portfolio firms will not provide a return on investment to IVCs. Four factors have been identified for the low IVC successful exit rate. One factor is diseconomy of scale. Cumming and Dai (2011) suggested a diseconomy of scale exists in the venture capital industry partially because of limitations of IVCs human capital as the fund size grows. IVCs tend to overextend by investing in too many portfolio firms following periods where fund inflows are increasing. IVCs often opt to invest in newer portfolio firms rather than investing more funds in existing portfolio firms (Bartkus et al., 2013).

The second factor is an emphasis on quick exits rather than building long-term sustainable companies. Because most IVC funds last approximately 10 years, IVCs want to turn funds over two or three times during the life of the fund to satisfy investors and to build a positive reputation within the venture capital industry. Bringing a portfolio company to an earlier-than-expected exit permits the IVC to raise more funding (Bartkus et al., 2013). Most IVCs focus on funding portfolio companies for two to five years or less and then hope to exit with high ROI. The emphasis of quick exists reduces the IVCs' focus on building market leading, high brand aware, and sustainable businesses benefiting economic activity.

The third factor is that a successful exit is independent of fund inflows. IVCs tend to invest in more portfolio firms after increased fundraising (Bartkus et al., 2013). When fundraising increases, IVCs tend to offer higher valuations and provide more capital, irrespective of portfolio company-estimated value (Bartkus et al., 2013). During times of enhanced fundraising, IVCs are more likely to invest in portfolio firms with a low probability of achieving a successful exit.

The fourth factor is that the IVC's association with a portfolio firm might be prearranged by financial and market forecasts concerning the type of exit (Gerasymenko \& Arthurs, 2014). Without understanding how the IVCs involvement in the portfolio company correlates with exit forecasts, the relationship between the IVCs value-added services and the portfolio company remains imperfect (Gerasymenko \& Arthurs, 2014). IVCs might exit not because of market conditions, but rather due to financial and market forecasts.

\section{CONCLUSION}

The reason IVCs have low success rates in turning portfolio firms into successful exits might not lie in the inherent nature of venture capital, conducting due diligence, or the staging process. Similar to demand-pull inflation, the demand for funding portfolio companies and the availability of funding from institutional and high net worth investors outpaces the supply of quality portfolio firms that can achieve a successful exist and return a high ROI. The reasons for poor exit rates are a result of a mix of diseconomy of scale in the venture capital industry, emphasis on quick exits rather than building companies, exits independent of fund inflows, and financial and market forecasts that appear to trump market conditions. If IVCs want higher exit rates, IVCs need to cease providing funding, especially during times of high capital inflows, and stop playing a numbers game by chasing portfolio firms that have little chance of achieving a successful exit.

\section{AUTHOR INFORMATION}

David Blum is an adjunct faculty mentor in the School of Business Management and Technology at Northcentral University. Dr. Blum holds a Bachelor's Degree in History from Bellarmine University, a Master of Business Administration (MBA) in Sustainable Business from Marylhurst University, and a Doctor of Business Administration (DBA) from Walden University. 


\section{REFERENCES}

1. Bamford, C. E., \& Douthett, E. B. (2013). Venture capital and risk management: Evidence from initial public offerings. Journal of Managerial Issues, 3, 220-240. Retrieved from http://www.questia.com/library/p4318/journal-of-managerial-issues\#/.

2. Bhagat, S. (2013). Why do venture capitalists use such high discount rates? The Journal of Risk Finance, 15, 94-98. doi:10.1108/JRF-08-2013-0055.

3. Bartkus, J. R., Hassan, M. K., \& Ngene, G. (2013). Does venture capital portfolio size matter. Studies in Economics and Finance, 30, 192-208. doi:10.1108/SEF-01-2012-0005.

4. Blum, D. A. (2013). Exploring best practice skills to predict uncertainties in venture capital investment decision-Making (Doctoral dissertation). Available from ProQuest Dissertations \& Thesis. (UMI Number: 3588186).

5. Blum, D. A. (2014). A venture capital handbook: Best practice strategies for investing in microalgae biodiesel. Huntsville, AL: Emerson Street Press.

6. Cumming, D., Schmidt, D., \& Walz, U. (2010). Legality and venture capital governance around the world. Journal of Business Venturing, 25, 54-72. doi:10.1016/j.jbusvent.2008.07.001.

7. Cumming, D., \& Dai, N. (2011). Fund size, limited attention and valuation of venture capital backed firms. Journal of Empirical Finance, 18, 2-15. doi:10.1016/j.jempfin.2010.09.00.

8. Dahiya, S., \& Ray, K. (2012). Staged investments in entrepreneurial financing. Journal of Corporate Finance, 18, 1193-1216. doi:10.1016/j.jcorpfin.2012.07.002.

9. Driouchi, T., Leseure, M., \& Bennett, D. (2009). A robustness framework for monitoring real options under uncertainty. Omega, 37, 698-710. doi:10.1016/j.omega.2007.09.004.

10. Ecer, S., \& Khalid, S. (2013). Stage-specific effects of the Sarbanes-Oxley Act. Journal of Entrepreneurship and Public Policy, 2, 110-129. doi:10.1108/JEPP-11-2011-0027.

11. Gerasymenko, V., \& Arthurs, J. D. (2014). New insights into venture capitalists' activity: IPO and time-toexit forecast as antecedents of their post-investment involvement. Journal of Business Venturing, 29, 405420. doi:10.1016/j.jbusvent.2013.06.003.

12. Geronikolaou, G., \& Papachristou, G. (2011). Is there an adverse effect of uncertainty on Venture Capital? The European evidence. Applied Economics Letters, 18, 383-388. doi:10.1080/13504851003670601.

13. Hsu, T. W. (2010). Staging of venture capital investment: a real options analysis. Small Business Economics, 35, 265-281. doi:10.1007/s11187-008-9158-2.

14. Jackson, W. E., Bates, T., \& Bradford, W. D. (2012). Does venture capitalist activism improve investment performance? Journal of Business Venturing, 27, 342-354. doi:10.1016/j.jbusvent.2011.02.003.

15. Kaplan, S. N., \& Lerner, J. (2010). It ain't broke: The past, present, and future of venture capital. Journal of Applied Corporate Finance, 22(2), 36-47. doi:10.1111/j.17456622.2010.00272.x.

16. Lehtonen, O., \& Lahti, T. (2009). The role of advisors in the venture capital investment process. Venture Capital an International Journal of Entrepreneurial Finance, 11, 229-254. doi:10.1080/13691060902972851.

17. Li, Y., \& Mahoney, J. T. (2011). When are venture capital projects initiated? Journal of Business Venturing, 26, 239-254. doi:10.1016/j.jbusvent.2009.08.001.

18. Li, Y., \& Zahra, S. A. (2012). Formal institutions, culture, and venture capital activity: A cross-country analysis. Journal of Business Venturing, 27, 95-111. doi:10.1016/j.jbusvent.2010.06.003.

17. NVCA. (2014). FAQ. Retrieved from http://www.nvca.org/index.php?Itemid=147.

18. Olsson, N. O. E., Frydenberg, S., Jakobsen, E. W., \& Jessen, S. A. (2010). In search of project substance: How do private investors evaluate projects? International Journal of Managing Projects in Business, 3, 257-274. doi:10.1108/17538371011036572.

19. Rajan, A. T. (2010). Venture capital and efficiency of portfolio companies. IIMB Management Review, 22, 186-197. doi:10.1016/j.iimb.2010.10.009.

20. Schertler, A., \& Tykvova, T. (2011). Venture capital and internationalization International Business Review, 20, 423-439. doi:10.1016/j.ibusrev.2010.07.009.

20. Smolarski, J., \& Kut, C. (2011). The impact of venture capital financing method on SME performance and internationalization. International Entrepreneur and Management Journal, 7, 39-55. doi:10.1007/s11365009-0128-1.

21. Strömsten, T., \& Waluszewski, A. (2012). Governance and resource interaction in networks. The role of 
venture capital in a biotech start-up. Journal of Business Research, 65, 232-244. doi:10.1016/j.jbusres.2010.11.030.

22. Wiltbank, R., Read, S., Dew, N., \& Sarasvathy, S. D. (2009). Prediction and control under uncertainty: Outcomes in angel investing. Journal of Business Venturing, 24, 116-133. doi:10.1016/j.jbusvent.2007.11.004.

23. Yung, C. (2009). Entrepreneurial financing and costly due diligence. The Financial Review, 44, 137-149. doi:10.1111/j.1540-6288.2008.00213.x.

24. Zhang, T. X., Aksu, B. P., \& Wang, H. (2012). Conflicts of interest in venture capital-backed IPO firms. Journal of International Finance \& Economics, 12(2), 50-59. Retrieved from http://www.iabe.org/domains/iabe/journal.aspx?journalid=11. 